\title{
National Register Testing at 41LT307, on CR 153 at the Navasota River, Limestone County, Texas
}

Timothy B. Griffith

Ross C. Fields

Follow this and additional works at: https://scholarworks.sfasu.edu/ita

Part of the American Material Culture Commons, Archaeological Anthropology Commons, Environmental Studies Commons, Other American Studies Commons, Other Arts and Humanities Commons, Other History of Art, Architecture, and Archaeology Commons, and the United States History Commons

Tell us how this article helped you.

This Article is brought to you for free and open access by the Center for Regional Heritage Research at SFA ScholarWorks. It has been accepted for inclusion in Index of Texas Archaeology: Open Access Gray Literature from the Lone Star State by an authorized editor of SFA ScholarWorks. For more information, please contact cdsscholarworks@sfasu.edu. 


\section{National Register Testing at 41LT307, on CR 153 at the Navasota River, Limestone County, Texas}

\section{Licensing Statement}

This is a work for hire produced for the Texas Department of Transportation (TxDOT), which owns all rights, title, and interest in and to all data and other information developed for this project under its contract with the report producer. The report may be cited and brief passages from this publication may be reproduced without permission provided that credit is given to TxDOT and the firm that produced it. Permission to reprint an entire chapter, section, figures or tables must be obtained in advance from the Supervisor of the Archeological Studies Branch, Environmental Affairs Division, Texas Department of Transportation, 125 East 11th Street, Austin, Texas, 78701. 


\title{
NATIONAL REGISTER TESTING AT 41LT307, ON CR 153 AT THE NAVASOTA RIVER, LIMESTONE COUNTY, TEXAS
}

\author{
by \\ Timothy B. Griffith \\ and \\ Ross C. Fields
}

Principal Investigator: Ross C. Fields

TECHNICAL REPORTS, NUMBER 76

Prewitt and Associates, Inc.

Cultural Resources Services

Austin, Texas

ARCHEOLOGICAL STUDIES PROGRAM, REPORT NO. 91

Texas Department of Transportation

Environmental Affairs Division

March 2007

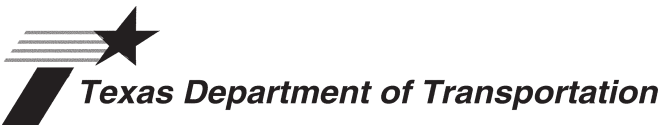

TEXAS ANTIQUITIES PERMIT NO. 3899 


\title{
NATIONAL REGISTER TESTING AT 41LT307, ON CR 153 AT THE NAVASOTA RIVER, LIMESTONE COUNTY, TEXAS
}

\author{
COPYRIGHT @ 2007
}

Texas Department of Transportation (TxDOT) and Prewitt and Associates, Inc. (PAI)

TxDOT and PAI jointly own all rights, title, and interest in and to all data and other information developed for this project under Contract 574XXSA002. Brief passages from this publication may be reproduced without permission provided that credit is given to TxDOT and PAI. Permission to reprint an entire chapter, section, figures or tables must be obtained in advance from the Supervisor of the Archeological Studies

Program, Environmental Affairs Division, Texas Department of Transportation, 125 East 11th Street, Austin, Texas, 78701.

\author{
jointly published by the \\ Texas Department of Transportation \\ Environmental Affairs Division \\ Archeological Studies Program \\ Lisa Hart, Director, Cultural Resources Management Section \\ Archeological Studies Program, Report No. 91 \\ Al McGraw, Series Editor \\ and \\ Prewitt and Associates, Inc. \\ Cultural Resources Services \\ Austin, Texas \\ PAI Project No. 206035
}

Technical Reports No.76

Printed by Morgan Printing in Austin, Texas

ISBN 930788-61-4 


\section{TABLE OF CONTENTS}

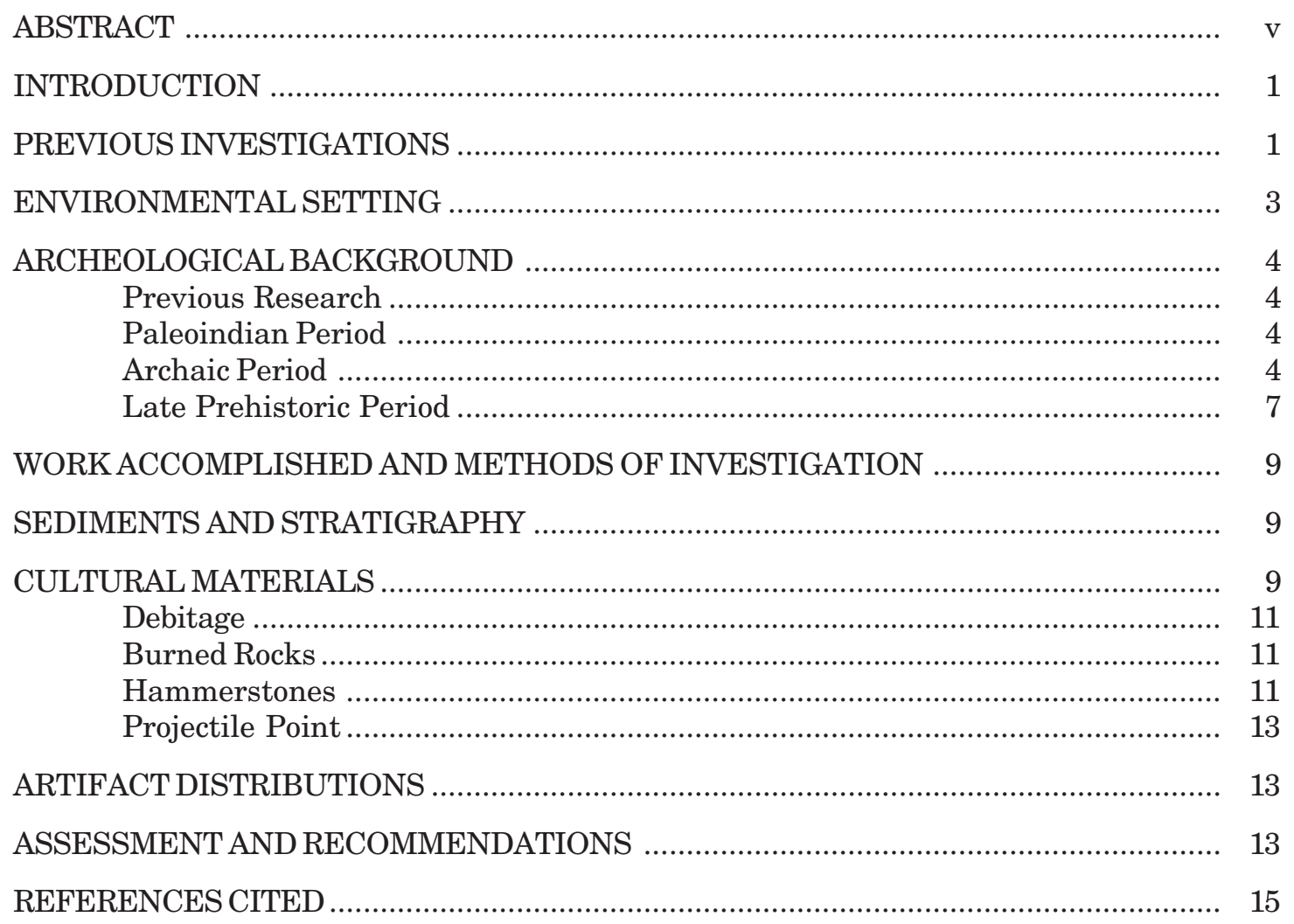




\section{LIST OF FIGURES}

1. Project location map ......

2. View to the north of 41LT307 on the floodplain of the Navasota River ............................. 3

3. Map of 41LT307 showing the locations of backhoe trenches and test units ...................... 10

4. Photograph of alluvial sediments exposed in the backhoe trench at 41LT307 .................. 11

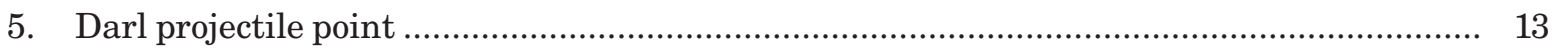

\section{LIST OF TABLES}

1. Provenience of cultural materials recovered from 41LT307 


\begin{abstract}
Archeological test excavations at 41LT307 were completed by Prewitt and Associates, Inc., in 2005 in conjunction with Texas Department of Transportation road improvements on County Road 153 in northwestern Limestone County. The site is situated on the active floodplain in Holocene alluvium adjacent to the Navasota River. Excavations revealed sparse lithic artifacts and no cultural features. No organic remains were recovered, and the age of the cultural occupation is unknown. The portion of 41LT307 inside the new right of way is considered ineligible for listing in the National Register of Historic Places or designation as a State Archeological Landmark. All artifacts were generated through a state-sponsored project and collected on state-owned property. All artifacts and records generated by this project are curated at the Texas Archeological Research Laboratory, The University of Texas at Austin.
\end{abstract}





\section{INTRODUCTION}

Archeological testing of site 41LT307 was conducted by Prewitt and Associates, Inc. (PAI), for the Texas Department of Transportation's (TxDOT) Environmental Affairs Division under Contract No. 575XXSA006, Work Authorization Nos. 57521SA006 and 57543SA006, and Texas Antiquities Permit No. 3899 issued by the Texas Historical Commission. Fieldwork was done on September 19-23, 2005. Laboratory processing and interim report preparation took place during September and October 2005. The work was done to assist TxDOT in complying with Section 106 of the National Historic Preservation Act and the Antiquities Code of Texas. A portion of the site extends into new right of way needed for the proposed replacement of the County Road 153 bridge over the Navasota River in Limestone County. The project proposes to replace the existing $22.9 \times 4.3-\mathrm{m}$ bridge with a new bridge $32 \mathrm{~m}$ long and $8 \mathrm{~m}$ wide. A small amount of new right of way will be needed on the east side of the road both north and south of the river, generally extending no more than $7.5 \mathrm{~m}$ beyond the existing right of way. No new right of way will be needed west of the road. The approaches will be reworked for distances of $59 \mathrm{~m}$ north and $64 \mathrm{~m}$ south of the ends of the new bridge. The current archeological investigations were restricted to the small area of proposed new right of way north of the river and east of the road.

Site 41LT307 is in northwest Limestone County approximately $40 \mathrm{~km}$ northeast of Waco, Texas (Figure 1). The site is situated at a maximum elevation of ca. $520 \mathrm{ft}$ above mean sea level on the floodplain north of the Navasota River adjoining the channel (Figure 2 ). The floodplain containing the site is an open pasture. The project area is mapped as Quaternary alluvial deposits (Bureau of Economic Geology 1970).

As described below, 41LT307 is a prehistoric site contained in late Holocene alluvium. Archeological testing through the excavation of one $22-\mathrm{m}$-long trench and three $1 \mathrm{x} 1-\mathrm{m}$ handdug units resulted in the recovery of a small artifact assemblage but no cultural features, datable materials, or faunal remains. The site appears to lack the capacity to contribute important information, and thus it is assessed as ineligible for listing in the National Register of Historic Places or designation as a State Archeological Landmark.

\section{PREVIOUS INVESTIGATIONS}

Personnel from PAI recorded 41LT307 in 2005 during an intensive survey for TxDOT's proposed CR 153 bridge replacement over the Navasota River (Griffith 2005). At that time, seven Gradall trenches were excavated, three in the northeast quadrant of the project area, two in the southwest quadrant, and one each in the northwest and southeast quadrants. Cultural materials were found only in the northeast quadrant. Trenches 4-6 were placed in this area, with Trench 4 being at the edge of the proposed new right of way and the other trenches being beyond the new right of way to the east. Visual inspection of this quadrant revealed two short gullies in the new right of way and the area just to the east extending from the cutbank of the river northward ca. $5 \mathrm{~m}$. Several burned rock fragments and pieces of chert debitage were encountered eroding from the cutbanks ca. $70-100 \mathrm{~cm}$ below the original ground surface. Further inspection revealed a Darl projectile point eroding out of the gully cutbank ca. $73 \mathrm{~cm}$ below the ground surface. Additional cultural materials were found in Trenches 4 and 5 in this area. The cultural materials were recorded as 41LT307.

Trench 4 at the east edge of the new right of way and Trench 5 ca. $15 \mathrm{~m}$ farther east revealed similar stratigraphic profiles, although Trench 4 was in an area where the upper ca. $40 \mathrm{~cm}$ of the floodplain deposits had been removed by erosion. The upper $20 \mathrm{~cm}$ consisted of a sandy silty loam that appeared not to contain cultural materials. Zone 2 between 20 and 90 to $105 \mathrm{~cm}$ consisted of a silty clay loam and contained a few burned rocks and pieces of chert debitage concentrated between 60 and $100 \mathrm{~cm}$. Dense clay was located below Zone 2 down to $225 \mathrm{~cm}$. No cultural materials were encountered in the clay deposit. Shovel Tests 1 and 2 were placed on the walls of Trenches 5 and 4, respectively, to better 


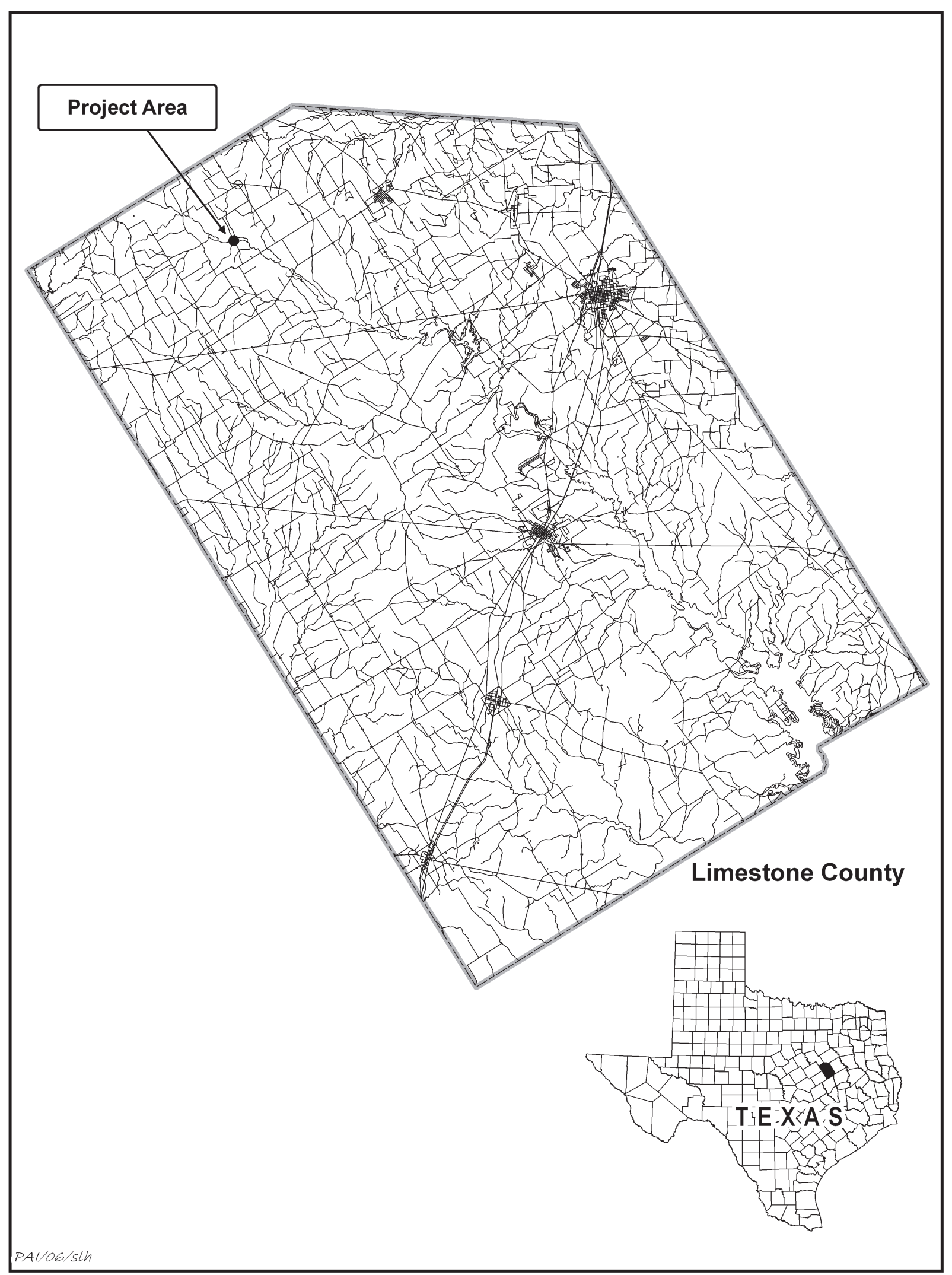

Figure 1. Project location map. 


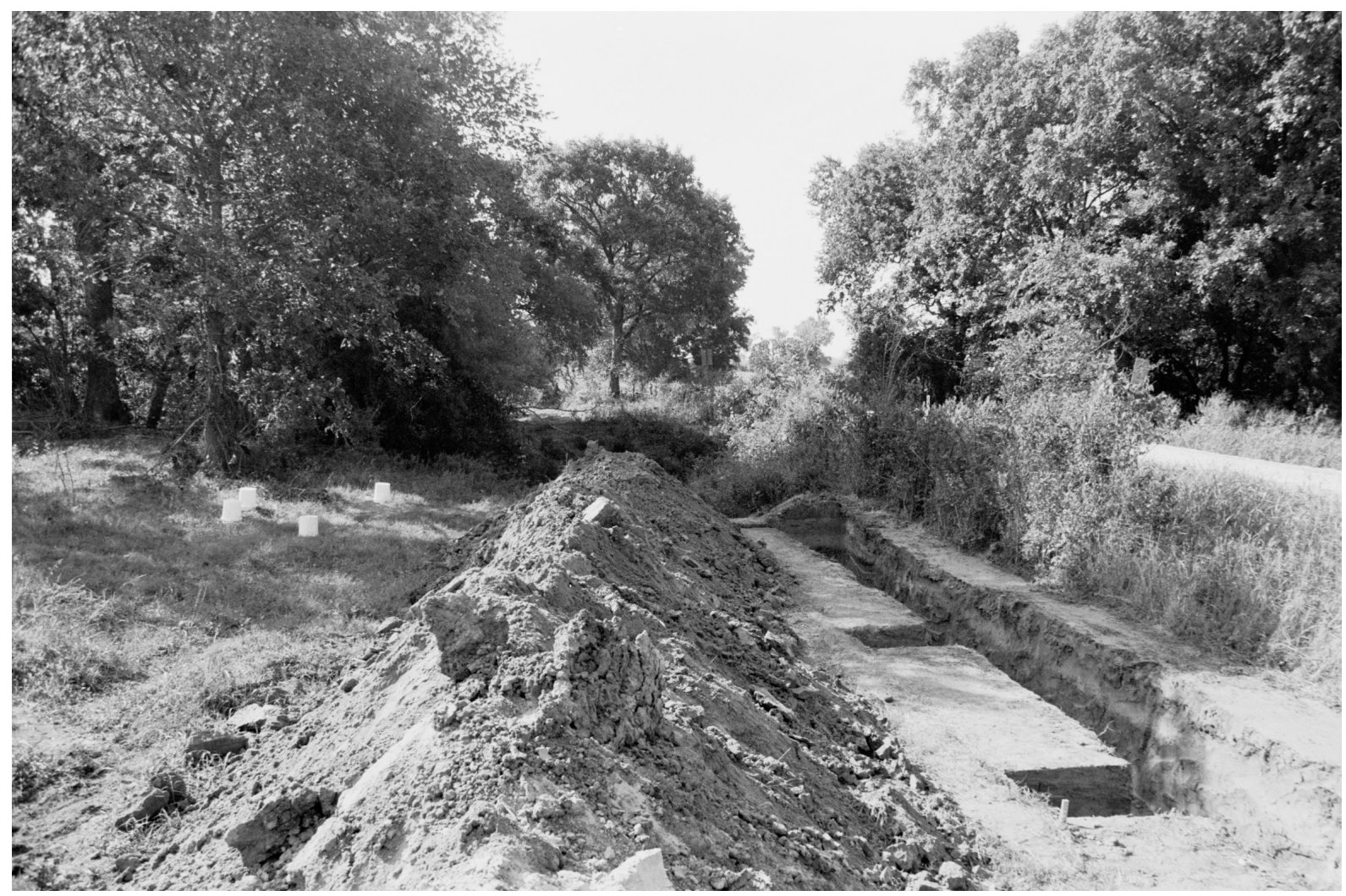

Figure 2. View to the north of 41LT307 on the floodplain of the Navasota River.

document the artifact densities and distributions. Shovel Test 1 was dug to $120 \mathrm{~cm}$ and contained one chert flake between 60 and $80 \mathrm{~cm}$. Shovel Test 2 also was dug to $120 \mathrm{~cm}$. The upper $20 \mathrm{~cm}$ (ca. $40-60 \mathrm{~cm}$ below the original surface) contained six burned rocks and three pieces of chert debitage. Next, between 20 and $40 \mathrm{~cm}(60-80 \mathrm{~cm}$ below the original surface), only two burned rocks were encountered. No other cultural materials were found in this shovel test. Trench 6, placed ca. $15 \mathrm{~m}$ north of Trenches 4 and 5, outside the proposed new right of way, did not contain any cultural materials, indicating that 41LT307 does not extend this far north. Based on the information from Trenches 4 and 5, 41LT307 appeared to be a light accumulation of cultural materials between 40 and $100 \mathrm{~cm}$ beneath the original ground surface. Based on the recovery of the single Darl point, it appeared to date at least partly to the Late Archaic period, which was consistent with its shallow burial in late Holocene alluvium. Further work was recommended to determine if isolable and interpretable cultural components are present and thus assess its National Register and State Archeological Landmark eligibility.

\section{ENVIRONMENTAL SETTING}

Limestone County is in the eastern part of central Texas at the boundary of the Blackland Prairie to the west and the Oak Woodlands to the east. Upper Cretaceous rocks, principally mudstones, marls, soft limestones, and chalk, support soils, vegetation, and landforms typical of the area. Soils of the Blackland Prairie are primarily Mollisoils and Vertisols and belong to the Houston-Black-Heiden-Branyon (shaley or marly uplands), Austin-Stephen-Altoga (chalky uplands), and Trinity-Frio-Bosque (valley alluvium) soil associations. Prior to landscape alterations of the twentieth century, the Blackland Prairie supported a mix of tall grasses (Blair 1950:100). Arboreal species (e.g., hackberry and elm ) were primarily limited to stream valleys, though scattered live oak 
mottes were present in some upland localities. The Oak Woodland region is characterized by overcup oak, post oak, and black hickory decidous forests and bluejack oak, pine, post oak, and blackjack oak decidous woodlands (Diamond et al. 1987). Fauna are typical of the Texan biotic province, which includes 49 species of mammals, 2 species of turtles, 16 species of lizards, 39 species of snakes, and 23 species of amphibians (Blair 1950:101-102).

As described in the soil survey for Limestone County (Griffin 1998), the climate of the region is characterized by hot summers and cool winters. During the winter months, an occasional surge of cold air can drop temperatures significantly. These cold spells are brief, and typically winter temperatures are mild. Mean daily maximum and minimum temperatures for winter are 48 and $36^{\circ} \mathrm{F}$; mean daily temperatures for summer are 94 and $82^{\circ} \mathrm{F}$ (Griffin 1998). The average annual rainfall is 40 inches. Fifty-one percent ( 21 inches) of the annual precipitation usually falls in April through September. Prevailing winds are from the south.

\section{ARCHEOLOGICAL BACKGROUND}

\section{Previous Research}

The archeology of northwestern Limestone County is not well understood because the immediate area has seen little archeological work. But enough work has been done in adjoining areas to provide some insights into the cultural history of this area. Among the projects that have contributed important information are Aquilla Lake in Hill County to the northwest (Brown 1987); Navarro Mills Reservoir, the Superconducting Super Collider, and Bardwell Lake to the north in Ellis County and eastern Hill County (Duffield 1963; Sorrow 1966; Yedlowski et al. 1998); Richland-Chambers Reservoir in Freestone and Navarro Counties to the northeast (Bruseth and Martin 1987; McGregor and Bruseth 1987); Jewett Mine to the east-southeast in Freestone and Leon Counties (Day 1984; Fields 1987, 1990; Fields and Klement 1995; Fields et al. 1991; Gadus et al. 2002); Lake Limestone to the southeast in
Leon, Limestone, and Robertson Counties (Mallouf 1979); Calvert Mine in Robertson County to the south (Davis et al. 1987; Robinson and Turpin 1993); and the State Highway 36Little River project in Milam County to the south (Gadus et al. 2006; Mahoney et al. 2003).

\section{Paleoindian Period}

As elsewhere in Texas, excavated and reported Paleoindian materials from the vicinity of 41LT307 are scarce to nonexistent, but a variety of early points have been found, largely in mixed or surface contexts, and it is clear that this part of Texas was used throughout the period from ca. 10,000 to 6500 B.C. Presumably, this use was by hunter-gatherer groups with low population densities and high residential mobility. Early materials from the region include several San Patrice or Brazos Fishtail and Plainview points from Aquilla Lake (Brown 1987:44-1 through 44-2); a handful of points typed as Clovis, Dalton, Golondrina, Plainview, and San Patrice, along with several untyped lanceolate specimens, in collections by C. K. Chandler and other avocational archeologists from sites mostly in Ellis County (Yedlowski et al. 1998:519-520); a cache of 23 prismatic blades from a site in Navarro County (Young and Collins 1989); the Brookeen Creek cache of 173 blades and flakes from Hill County (Mallouf 1981); a few San Patrice points from Richland-Chambers Reservoir (McGregor and Bruseth 1987:176-179); one Folsom point from Lake Limestone (Mallouf 1979:44); and a Golondrina point, several untyped lanceolate points, and a radiocarbon assay of 8940 B.P. from the Lambs Creek knoll site at the Jewett Mine (Fields 1995:304), as well as a Clovis point, a Meserve-Dalton point, and two San Patrice points from two other Jewett Mine sites (Day 1984:83; Fields et al. 1991:317).

\section{Archaic Period}

Some excavated sites in the region have components dating to the Archaic period (ca. 6500 B.C.-A.D. 700), but materials dating to the Early and Middle parts of the period are not 
very abundant. A variety of projectile point styles traditionally associated with the Early and Middle Archaic periods of central Texassuch as Andice, Angostura, Bell, Gower, Hoxie, Martindale, Nolan, Travis, and Uvalde-were identified in private artifact collections analyzed for the Superconducting Super Collider project just to the north in Ellis County (Yedlowski et al. 1998:520). These points are few in number, however, and do not appear to represent major occupations of this part of the Blackland Prairie. Unequivocal early point styles were even scarcer at the nearby Pecan Springs site at Bardswell Reservoir and the Strawn Creek site at Navarro Mills Reservoir, with a Hoxie point from Pecan Springs being the clearest example (Duffield 1963; Sorrow 1966). Similarly, Early to Middle Archaic points-including Angostura, Bell/ Andice, Gower, Hoxie, and Martindale-were found only in small numbers at Aquilla Lake (Brown 1987:44-12 through 44-21), suggesting limited use of the valleys of Aquilla and Hackberry Creeks during this time.

The relatively intensive work at RichlandChambers Reservoir and Lake Limestone and Jewett Mine suggests limited use of the western edge of the Oak Woodlands before the Late Archaic, although for both areas it has been noted that data pertaining to the Early to Middle parts of the Archaic may be scarce in part because sites dating to this interval lie deeply buried or were removed by extensive erosion during the mid-Holocene (Fields 1995:302; McGregor and Bruseth 1987:229). Only a few radiocarbon assays predating 4000 B.P. were obtained from these project areas, and only one excavated site, Charles Cox at the Jewett Mine, contains a substantial component that might be Early or Middle Archaic in age (Fields 1995:303-305). A variety of untyped dart points with expanding and parallel stems appear to represent this component, but later materials are mixed in as well, and the deposits were not dated by radiocarbon. Points dated to this interval in central Texas-for example, Bell, Andice, Calf Creek, and Hoxie-occur at both Richland-Chambers Reservoir and the Jewett Mine, but only in very small numbers.

Given the limited information available, it is difficult to say much about adaptations and lifeways during the Early and Middle Archaic periods. It does appear, however, that the region was used in a limited fashion, presumably reflecting low population densities among mobile hunter-gatherers. The latter part of the Archaic period-that is, after about 4000 B.P.presents a different picture of more-intensive occupation. Both the Pecan Springs and Strawn Creek sites yielded such Late Archaic point types as Dawson, Gary, and Yarbrough, although they tended to be mixed with materials from later occupations (Duffield 1963:60-62; Sorrow 1966:56-61). The surface collections analyzed during the Superconducting Super Collider project also contained these types, as well other Late Archaic types common to central Texas-such as Bulverde, Darl, Ensor, Marcos, Marshall, Montell, and Pedernales-and a variety of probable Late Archaic forms more characteristic of north-central and eastern Texas, such as Carrollton, Edgewood, Elam, Ellis, Kent, and Neches River (Yedlowski et al. 1998:520-521). Noting the relatively high frequency of Late Archaic projectile points, Yedlowski et al. (1998:527-528, 533) suggest that the region saw an increase in use by hunter-gatherers as a result of moister climatic conditions than before, presumably associated with greater productivity in subsistence resources. They also note that, although the projectile point evidence indicates interaction with groups living in central Texas proper, larger proportions of points indicate affinities with eastern Texas than during the Early and Middle Archaic. Brown (1987:44-22 through 4426) presents similar conclusions concerning an increase in occupational intensity and increased interaction to the north and east during the Late Archaic for the Aquilla Lake area based on an increase in the number of sites with Late Archaic diagnostics and the dominance of the Gary dart point type.

South of 41LT307 on the Little River in Milam County, both 41MM340 and 41MM341 have Late Archaic components, although only the one at $41 \mathrm{MM} 340$ was investigated intensively (Gadus et al. 2006; Mahoney et al. 2003). This site, which was occupied from about 1400 to 400 B.C., contained numerous hearth features represented by both burned rock clusters and charcoal and burned clay concentrations. Subsistence data indicate that the hunter-gatherers who occupied the Little River valley at this time consumed the meat of a variety of animals, including mussels, deer, 
bison, turtles, beaver, rabbits, raccoon, opossum, skunk, turkey, ducks, and fish. Botanical remains were not as abundant, although nut shell fragments indicate that hickory and pecan nuts were part of the diet. Most of the dart points belong to types that firmly tie this part of the region to central Texas to the west at this time, including Darl, Ensor, Godley, Marcos, Marshall, and especially Pedernales. Some more-eastern types, such as Gary, Kent, and Yarbrough, are represented, however

One of the more-complete pictures of the archeology of the Late Archaic for this region comes from the Oak Woodlands east of 41LT307. Along Richland and Chambers Creeks, Late Archaic groups appear to have been huntergatherers whose subsistence pursuits focused on wild plant foods such as hickory nuts and prairie turnip and animals such as deer, turtles, small mammals, birds, and fish (McGregor and Bruseth 1987:236-240). Although presumably not sedentary, these groups clearly used the area intensively for residential purposes, and populations appear to have increased. A conspicuous component of the record is the socalled Wylie pit, examples of which were excavated at the Bird Point Island and Adams Ranch sites. These were large features that appear to have been used for communal processing of vegetal resources (and later as cemeteries), perhaps in the context of band aggregation in tension zones as territories decreased in size (McGregor and Bruseth 1987:237).

The Navasota River valley and the area eastward to and across the Trinity River divide also were occupied with increased intensity during the Late Archaic period (Fields 1995:307-309), although there is no evidence for the kind of population aggregations indicated at Richland-Chambers Reservoir. Faunal and macrobotanical remains were not preserved in the Late Archaic components at Lake Limestone and the Jewett Mine, except for the ubiquitous hickory nut shells, and thus data on subsistence are limited. Nonetheless, it is surmised that these hunter-gatherers subsisted on a variety of wild plant foods and game, especially deer. Of the 20 excavated components assigned to this period, 15 are interpreted as residential bases and 5 as procurement or processing locations. Five of the residential-base components are situated along the Navasota River and appear to represent general-purpose campsites, and the others are in the uplands to the east and consist of 2 general-purpose residential bases and 8 residential bases at which activities focused heavily on plant processing and secondarily on hunting. This distinction suggests that Late Archaic settlement systems were based on the occurrence of plant foods. The analysis units interpreted as procurement-processing locations appear to have focused primarily on plant processing and then on hunting-related activities. Four of these are along streams in the uplands, and the fifth is along a Navasota River tributary to the west. The data from these 20 components are consistent with the idea that Late Archaic groups were chiefly foragers because procurement-processing locations suggesting logistical use are not frequent. Settlement systems appear to have been highly scheduled, probably by season, with residential sites in riverine settings differing from those in the uplands. Comparisons with earlier components at Lake Limestone and the Jewett Mine are difficult, but the much greater frequency of Late Archaic components and the overall greater intensity of use suggest increased population densities, decreased territories, or both. The occurrence of a Late Archaic cemetery at the Cottonwood Springs site along Lambs Creek on the east side of the Navasota River valley also points to this shift (Fields and Klement 1995).

Not only do constellations of projectile point styles (e.g., Dawson, Gary, Godley, Kent, Neches River, and Yarbrough) from the Richland-Chambers, Lake Limestone, and Jewett Mine areas indicate ties to the north and east rather than to the south and west, but each of these areas also has yielded information suggesting that ceramics may have been introduced into the material culture of local groups during the latest part of the Late Archaic, as they were across most of Texas to the east (where this interval usually is called the Early Ceramic period and sometimes the Woodland period).

At Richland-Chambers Reservoir, distinctive shell-tempered sherds were recovered from contexts dated between A.D. 200 and 700 at the Adams Ranch site (McGregor and Bruseth 1987:180-181), apparently 
representing the earliest ceramic industry in this part of the Trinity River basin. At Lake Limestone and the Jewett Mine, a few shelltempered sherds, a few sherds with a fine kaolin paste but no obvious temper, and larger numbers of sandy paste ceramics and grog- or bonetempered ceramics were found in contexts that appeared to predate arrow points (i.e., the latter part of the Late Archaic). Although some of these could be genuinely early, especially the sandy paste wares that are so reminiscent of the early ceramics that predominate in east Texas south of the Sabine River, it is possible that the other sherds intruded from later deposits (Fields 1995:308). In either case, sherds were sufficiently infrequent to suggest that, although ceramic containers may have been a notable addition to the material culture, they were not abundant.

\section{Late Prehistoric Period}

Sites dating to the Late Prehistoric period, after A.D. 700, also are relatively common. The collections analyzed during the Superconducting Super Collider project contain substantial numbers of both early (e.g., Alba, Bonham, Catahoula, Colbert, Scallorn, and Steiner) and late (e.g., Cliffton and Perdiz) arrow points, but Yedlowski et al. (1998:521, 527) note that early arrow points are more frequent, perhaps reflecting continued high population densities from the Late Archaic period. Other than the Perdiz and Scallorn types, which have such widespread distributions, the arrow point styles suggest strong ties to the east and north. The limited ceramic samples, containing sherds reminiscent of types such as Killough Pinched, Maydelle Incised, Poyner Engraved, and Weches Fingernail Impressed, also support interaction with Caddoan groups to the east (Yedlowski et al. 1998:521-522). The Strawn Creek site presents a similar picture, with most of the typed arrow points dating to the first half of the Late Prehistoric period and the moredistinctive ceramics in the small collection relating to the early Caddoan types Crockett Curvilinear Incised and Weches Fingernail Impressed (Duffield 1963).

Occupations dating to the early and late parts of the Late Prehistoric period also are represented at Aquilla Lake at the western edge of the Blackland Prairie, with the strongest components at the McDonald and Brazil sites (Brown 1987:44-27). Almost all of the small ceramic sample was from one site, McDonald. Among the ceramics are specimens that could be related to the Caddoan types Canton Incised, Kiam Incised, and Maydelle Incised, pointing to interaction with groups living to the east and northeast. The faunal sample from the McDonald site indicates that these hunter-gatherers relied on deer, turtles, fish, and mussels; bison were used only during the latter part of the period (Brown 1987:38144).

Recent excavations at the J. B. White site (41MM341) on the Little River in Milam County have shed new light on Late Prehistoric use of this part of the Blackland Prairie (Gadus et al. 2006). The excavations focused on broad exposure of the remains of a series of Late Prehistoric occupations dating from to A.D. 800 or 900 to 1300 . Analysis of the data recovered indicates that $41 \mathrm{MM} 341$ was a campsite occupied perhaps mostly during the summer months by local hunter-gatherers who took mussels and fish from the river and hunted a variety of game, especially deer, on the Little River floodplain and the surrounding uplands. They may have used botanical resources less, although they did consume hardwood nuts and wild onion and false garlic bulbs. One important activity performed at the site was manufacture of stone tools, mostly arrow points (Alba, Perdiz, and Scallorn), Friday and Gahagan knives, and expedient flake tools, using chert collected from gravel bars in the river. Many of these tools were used in the wide variety of procurement, processing, and manufacturing activities that typified daily life at 41MM341, but some appear to have been made because they would be needed later in the year after people left the site. One anticipated need was for trade with the Caddo Indians of east Texas. The people who lived at 41MM341 and other sites in the Little River valley interacted regularly with the Caddo, perhaps in trade relationships that helped cement cooperative alliances aimed at regulating competition among groups. Unlike in some other parts of the region, though, this trade did not result in local groups acquiring ceramic vessels from the Caddo, at least in appreciable numbers. 
Sites in the Oak Woodlands east of 41LT307 tell a different story. Sites dating to this interval are frequent at Richland-Chambers Reservoir, especially for the early half of the period, and it appears that there was a significant decline in population densities after about A.D. 1300 (McGregor and Bruseth 1987:245). The data suggest that most of the excavated sites with Late Prehistoric components were used for residential purposes (McGregor and Bruseth 1987:241, 244, 246), although there are some sites, for example the streamside concentrations of mussel shells and artifacts at $41 \mathrm{FT} 193$ and $41 \mathrm{NV} 139$, that probably had more-limited use. The house patterns at the Bird Point Island site point to intensive use by sedentary hunter-gatherers during the first half of the period, and other components that are contemporaneous, slightly earlier, or later (for example, at Bird Point Island, Adams Ranch, Irvine, and Little Cedar Creek) have middens and many features suggesting intensive use but no houses. These components may represent occupations that were seasonal in length. Macrobotanical remains point to use primarily of wild plant foods-hardwood nuts, a variety of seeds, tubers, and rhizomes (McGregor and Bruseth 1987:243). The only tropical cultigen is maize, and it occurs in very small quantities only in contexts dating to the last half of the period, so groups who lived in this area were predominantly hunters and gatherers. Alba, Scallorn, and Steiner arrow points were used during the early part of the period, and Perdiz and Cliffton points are more characteristic of the late part. Gary dart points may have been used through the early Late Prehistoric (McGregor and Bruseth 1987:183). Ceramics are moderately common and clearly relate to Caddoan wares, with most of the identified types (for example, Maydelle Incised, Poyner Engraved, and Weches Fingernail Impressed) indicating contact with groups in the Neches River drainage, east of the Trinity.

Work at Lake Limestone along the Navasota River and the Jewett Mine in the uplands to the east identified 12 components dating predominantly to the Late Prehistoric period, although not all are well dated (Fields 1995:313-317; Gadus et al. 2002). Six are interpreted as residential bases, and the other 6 are procurement-processing locations. These sites suggest that the Late Prehistoric period saw a change in settlement strategies from the Late Archaic and that there were changes within the Late Prehistoric period as well. During the early part of the period, residential activities were increasingly restricted to lowland sites, while the uplands were used mostly for hunting-related procurement and processing tasks. This pattern indicates that logistical strategies became more important, but there is no evidence that groups also became more sedentary within the upper Navasota River basin itself. Only one site, McGuire's Garden, contained the kinds of features and other remains that suggest permanent (or nearly so) occupation, with this unusually sedentary use dating to a short interval around A.D. 1300. During the late part of the period, the area apparently saw a return to forager-oriented hunter-gatherer strategies entailing more equable use of upland and lowland settings. Faunal remains indicate that deer, turtles, and rabbits were hunted commonly. Hickory nut shells are by far the most common plant remains. The only evidence for horticulture came from the McGuire's Garden site. Scallorn and Steiner are the most common early arrow point styles, and use of dart points appears to have persisted through the early part of the period (Fields 1995:314). Perdiz is the dominant later arrow point style. Ceramics occur widely but infrequently, being common at only a handful of sites that date mostly to the middle and late parts of the period. Nonetheless, they all relate strongly to Caddoan wares from east of the Trinity River, with the more-distinctive sherds showing typological affinities to early types such as Holly Fine Engraved and Weches Fingernail Impressed and later types such as Maydelle Incised, Killough Pinched, Poyner Engraved, and Patton Engraved. Because Caddoan ceramics are present in these components but evidence for permanent occupations (i.e., structures) is scarce, Fields et al. (1991) suggested that Caddo Indians used most of these sites as base camps to support forays by hunting parties or other procurement and processing task groups, or perhaps groups in transit between the eastern and central parts of the state used them. It is equally plausible, however, that local hunter-gatherer groups created them and that the ceramics resulted 
from trade or borrowing of ideas about ceramic manufacture and decoration.

\section{WORK ACCOMPLISHED AND METHODS OF INVESTIGATION}

Test excavations consisted of excavating a single 22-m-long north-south trench (Trench 8 ) between Trench 4 dug during survey and the edge of the existing right of way (Figure 3). Three 1x1-m units were then excavated next to the trench. Test unit depths ranged between 100 and $120 \mathrm{~cm}$ below the ground surface. The three test units were excavated in 10-cm levels, and the volume of sediment manually excavated and screened totaled $3.4 \mathrm{~m}^{3}$. Placement of all units was based on the presence of cultural materials in the trench walls. All sediments removed were screened through 1/4-inch-mesh hardware cloth. Due to the clayey sediments, water screening was used. This entailed placing the excavated sediments into buckets tagged with horizontal and vertical provenience information, soaking the sediments in a mixture of water and baking soda (as a deflocculating agent), and finally rinsing the sediments through $1 / 4$-inch screens. A water-holding sump was excavated just outside the northern boundary of the site to retain the runoff from screening. Excavation of test units was terminated at 100 or $120 \mathrm{~cm}$ below the ground surface. Soil stratigraphy was recorded and described for the trench and all test units by the project archeologist. Mapping was done with a total data station set at an arbitrary elevation of $100.00 \mathrm{~m}$. All excavations were backfilled at the completion of fieldwork. All trench excavations were monitored by the project archeologist, and the trench wall was inspected for cultural materials.

All cultural materials recovered were bagged in the field and then returned to PAI's laboratory. All relevant provenience data was labeled on each bag before it left the field. Artifact counts by test unit and level were recorded in the field to assist in tracking artifact frequencies and distributions across the site. The final step of fieldwork consisted of electronic mapping of both topographic features and the positions of the trench and all test units.

\section{SEDIMENTS AND STRATIGRAPHY}

Site 41LT307 is situated on a broad, nearly level floodplain that stands ca. 3-4 $\mathrm{m}$ above the Navasota River channel. Mollisols of the Whitesboro soils of the Houston Black-FerrisHeiden complex consisting of deep soils formed in loamy alluvial sediments are mapped in the project area (Griffin 1998). The deposits were inspected throughout the trench, in the test units, and along the river channel. They consist of late Holocene overbank deposits. These are dark brown to brown (10YR 4/2, 5YR 3/4, and 10YR 3/4) sandy silty loams, silty clay loams, and dense clay.

Three basic stratigraphic zones were observed throughout the trench and test units (Figure 4). These deposits are imprinted with an A/Ap-Bw-C soil profile. The A/Ap horizon consists of a sandy silty loam with a medium subangular blocky structure (10YR 4/2) extending from the surface down to ca. 20$30 \mathrm{~cm}$. This zone contains no cultural materials. A clear smooth lower boundary separates the Ap horizon from the underlying $\mathrm{Bw}$ horizon. Located down to $40-60 \mathrm{~cm}$, the Bw horizon is a sandy silt loam (5YR 3/4 to 10YR 3/4). It exhibits a weak medium subangular blocky structure. Its lower boundary is also clear and smooth. The $\mathrm{C}$ horizon is a dense clay present down to $225 \mathrm{~cm}$. Small alluvial gravels are scattered throughout each of the three stratigraphic zones.

The high sand content in Zones 1 and 2 is indicative of high-energy flood episodes during sedimentation. The underlying Zone 3 with low sand and high clay content reflects lower-energy deposition. This suggests that Zone 3 aggraded more slowly than Zones 1 and 2 and that the cultural materials in Zone 2 may have been more disturbed by flooding than those in Zone 3 .

\section{CULTURAL MATERIALS}

Cultural materials collected from 41LT307 during testing consist of debitage, hammerstones, and burned rocks. Only 16 pieces of lithic debitage, 3 quartzite hammerstones, and 12 burned rocks were recovered (Table 1). No other cultural materials, 


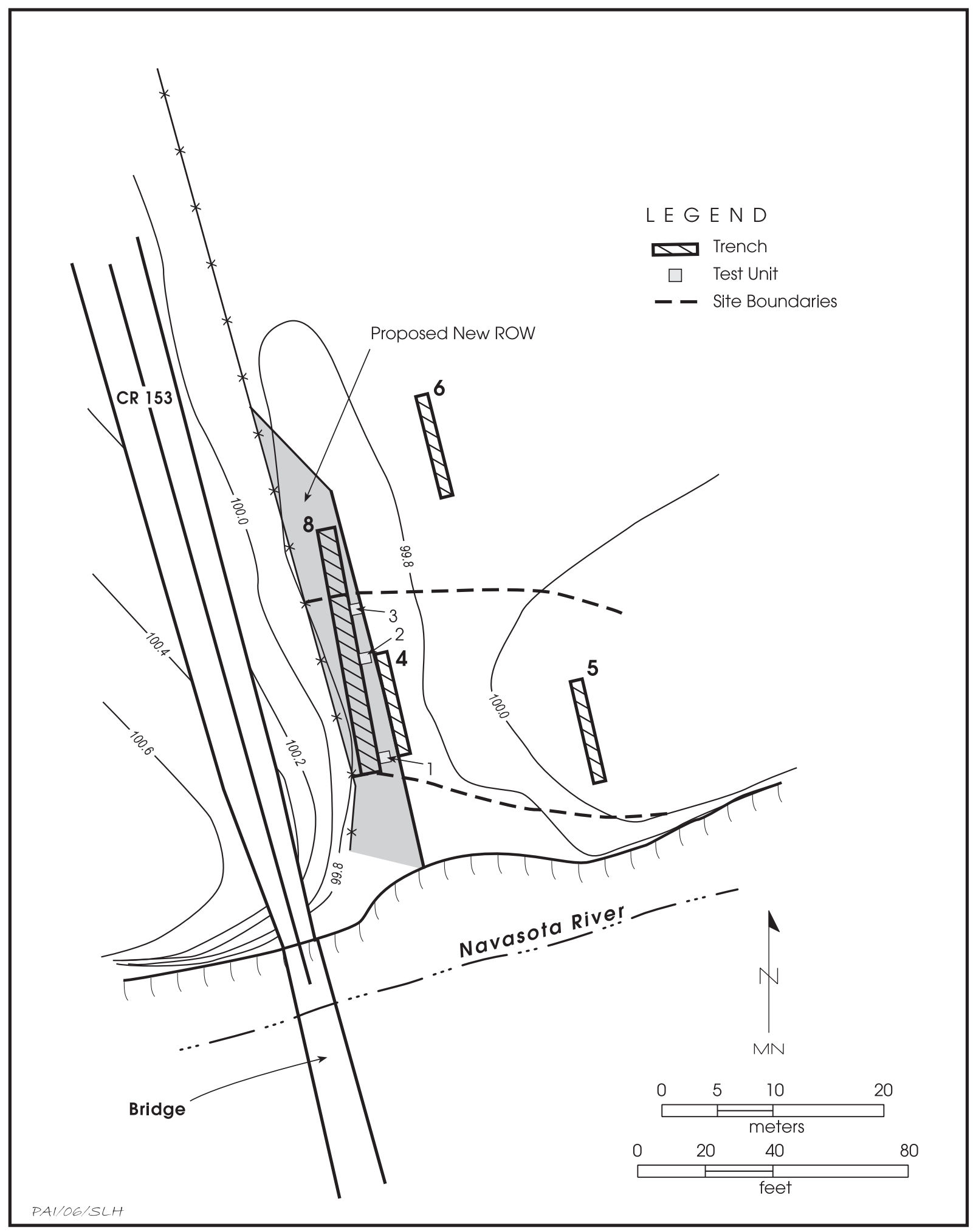

Figure 3. Map of 41LT307 showing the locations of backhoe trenches and test units. 


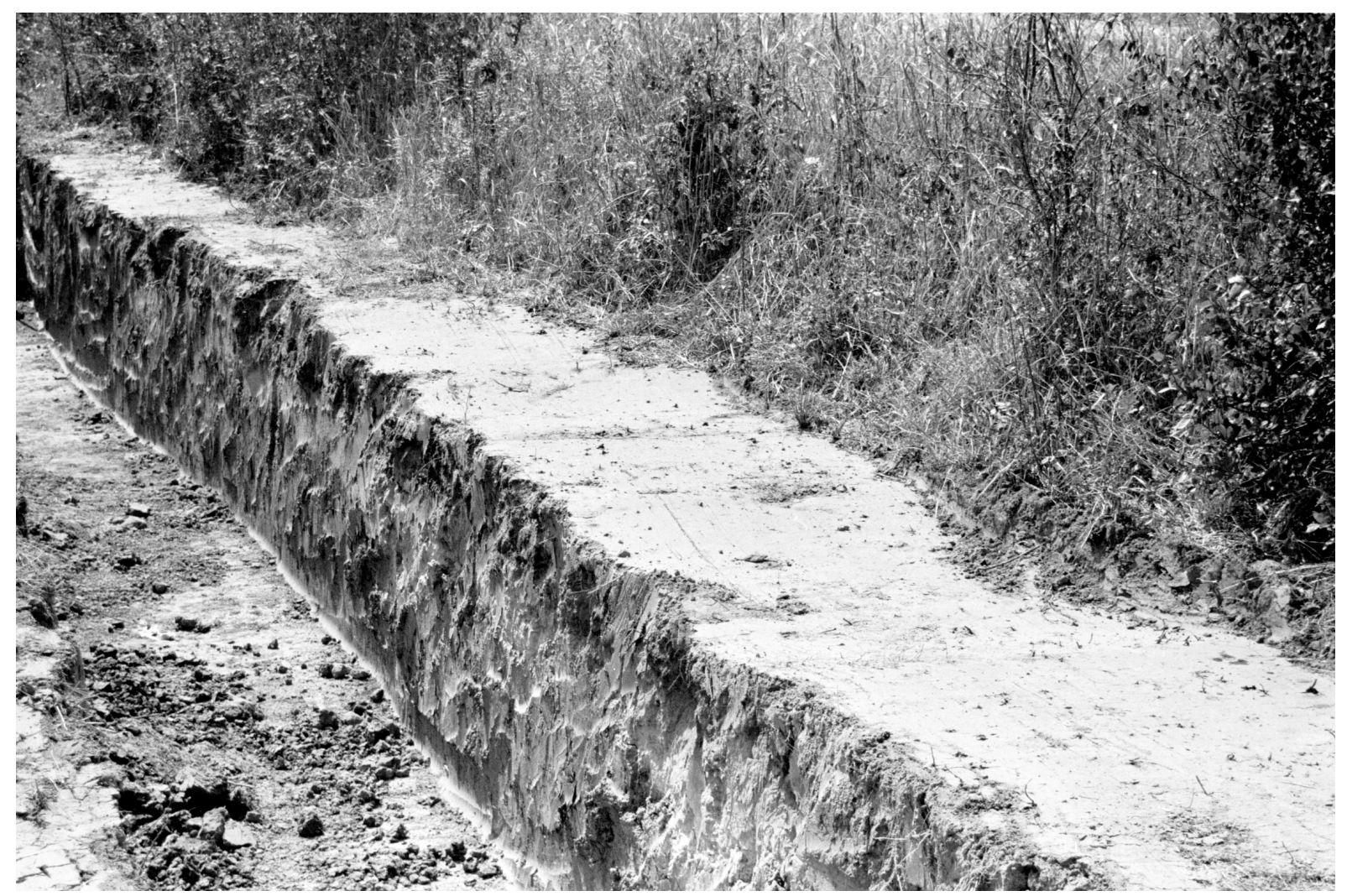

Figure 4. Photograph of alluvial sediments exposed in the backhoe trench at 41LT307, looking northeast.

such as chipped stone tools, charcoal or other macrobotanical remains, or faunal remains, were found, and no cultural features were encountered. Though not recovered during this phase of work, one projectile point found during the original 2005 survey is described here because it is temporally diagnostic.

\section{Debitage}

Sixteen pieces of unmodified debitage were recovered. All of these are chips. All these appear to be from secondary chert gravel sources. Most ( $\mathrm{n}=10,63$ percent) have no dorsal cortex. Three pieces have less than 50 percent, and 3 pieces have more than 50 percent cortex. In terms of size, 56 percent are between 10 and $20 \mathrm{~mm}$. None of the debitage shows thermal alterations. Material color ranges from light tan to gray. Grain size ranges from small to medium. The characteristics of the debitage suggest that mainly late-stage lithic reduction is represented.

\section{Burned Rocks}

Burned rocks also were uncommon. Only 12 fragments were found lightly scattered throughout the test units. None were associated with any recognizable feature pattern. These materials were not collected but quantified in the field. All burned rocks were angular pieces of fire-cracked limestone weighing less than $0.5 \mathrm{~kg}$.

\section{Hammerstones}

One of the three hammerstones is a small fragment that is $55.0 \mathrm{~mm}$ long, $32.0 \mathrm{~mm}$ wide, 
Table 1. Provenience of cultural materials recovered from 41LT307

\begin{tabular}{|c|c|c|c|c|c|}
\hline Test Unit & Elevation (m) & Debitage & $\begin{array}{c}\text { Burned } \\
\text { Rocks }\end{array}$ & $\begin{array}{c}\text { Hammer- } \\
\text { stones }\end{array}$ & Total \\
\hline \multirow[t]{10}{*}{ TU 1} & $99.55-99.45$ & & & & 0 \\
\hline & $99.45-99.35$ & 2 & & & 2 \\
\hline & $99.35-99.25$ & 2 & & & 2 \\
\hline & $99.25-98.15$ & & 2 & & 2 \\
\hline & 99.15-99.05 & & 2 & & 2 \\
\hline & $99.05-98.95$ & 1 & & & 1 \\
\hline & $98.95-98.85$ & & & & 0 \\
\hline & $98.85-98.75$ & & & & 0 \\
\hline & $98.75-98.65$ & & & & 0 \\
\hline & $98.65-98.55$ & & & & 0 \\
\hline Subtotal & & 5 & 4 & & 9 \\
\hline \multirow[t]{12}{*}{ TU 2} & $99.66-99.56$ & & & & 0 \\
\hline & $99.56-99.46$ & & & & 0 \\
\hline & $99.46-99.36$ & & & & 0 \\
\hline & $99.36-99.26$ & & 1 & & 1 \\
\hline & $99.26-99.16$ & 3 & 1 & & 4 \\
\hline & $99.16-99.06$ & 1 & 1 & & 2 \\
\hline & $99.06-98.96$ & 3 & & & 3 \\
\hline & $98.96-98.86$ & & & & 0 \\
\hline & $98.86-98.76$ & & & & 0 \\
\hline & $98.76-98.66$ & & & & 0 \\
\hline & $98.66-98.56$ & & & & 0 \\
\hline & $98.56-98.46$ & & & & 0 \\
\hline Subtotal & & 7 & 3 & & 10 \\
\hline \multirow[t]{12}{*}{ TU 3} & $99.66-99.56$ & & & & 0 \\
\hline & $99.56-99.46$ & & & & 0 \\
\hline & $99.46-99.36$ & & & & 0 \\
\hline & $99.36-99.26$ & 1 & & & 1 \\
\hline & $99.26-99.16$ & & 3 & & 3 \\
\hline & $99.16-99.06$ & 1 & 1 & 2 & 4 \\
\hline & $99.06-98.96$ & & 1 & 1 & 2 \\
\hline & $98.96-98.86$ & 2 & & & 2 \\
\hline & $98.86-98.76$ & & & & 0 \\
\hline & $98.76-98.66$ & & & & 0 \\
\hline & $98.66-98.56$ & & & & 0 \\
\hline & $98.56-98.46$ & & & & 0 \\
\hline Subtotal & & 4 & 5 & 3 & 12 \\
\hline Total & & 16 & 12 & 3 & 31 \\
\hline
\end{tabular}

and $33.0 \mathrm{~mm}$ thick. Some evidence of bashing is present on two ends of this fragment. The other two specimens are nearly complete. One is $72.0 \mathrm{~mm}$ long, $51.5 \mathrm{~mm}$ wide, and $34.1 \mathrm{~mm}$ thick. This particular specimen contains evidence of bashing in three locations. The other is $62.7 \mathrm{~mm}$ long, $45.7 \mathrm{~mm}$ wide, and $40.0 \mathrm{~mm}$ thick and contains evidence of bashing on three sides. All three specimens are of quartzite. 


\section{Projectile Point}

During the initial survey, a single Darl projectile point was recovered at $70-80 \mathrm{~cm}$ below the surface along a gully cutbank ca. 10 $m$ north of the Navasota River channel (Figure 5). It is $58.1 \mathrm{~mm}$ long, $21.2 \mathrm{~mm}$ wide, and $9.2 \mathrm{~mm}$ thick. There is slight beveling along both blade edges. The stem is slightly flared. Some edge grinding is present on the stem. The material is a fine-grained, light gray to tan chert with medium to dark brown banding.

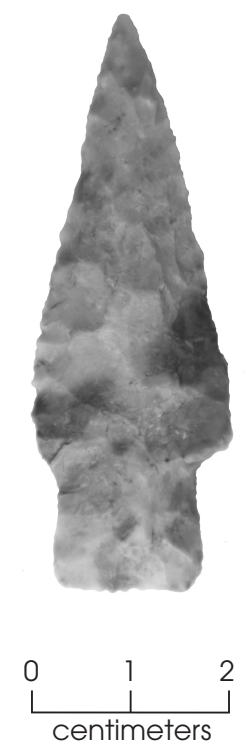

Figure 5. Darl projectile point.

\section{ARTIFACT DISTRIBUTIONS}

Artifacts are equally sparse in all three test units, and the cultural materials are not concentrated more in one particular area than another (see Table 1). Test Unit 1 contained five pieces of debitage, Test Unit 2 contained seven, and Test Unit 3 contained four pieces. All three of the hammerstones were recovered from Test Unit 3. Burned rocks were also sparsely scattered across the site. Four were recovered from Test Unit 1, three from Test Unit 2, and five from Test Unit 3. The one Darl-like point recovered during survey was found ca. $5 \mathrm{~m}$ southwest of Test Unit 1.
Because no artifacts were observed in the north end of Trench 8, the part of 41LT307 that is within the new right of way appears to extend no more than $30 \mathrm{~m}$ from the bank of the Navasota River. This is consistent with the absence of cultural materials in Trench 6 dug during survey, which was ca. 7.5 m northeast of the north end of Trench 8 .

Vertically, the cultural materials are restricted to a ca. 50-cm-thick zone. The cultural zone is present between 99.45 and $98.95 \mathrm{~m}$ in Test Unit 1, 99.36 and $98.96 \mathrm{~m}$ in Test Unit 2, and 99.36 and $99.86 \mathrm{~m}$ in Test Unit 3. The cultural zone contains only a limited amount of cultural materials and no features. When densities per cubic meter are compared, no distinct differences are observed. Test Unit 1 contained 18 items per cubic meter, Test Unit 2 had 25, and Test Unit 3 had 24. No significant differences in the distribution of debitage and burned rocks are noticeable. Most of the burned rocks are small and lightly scattered throughout the cultural zone. None of the burned rocks were associated with intact features.

No charcoal or other organic materials were recovered. The one projectile point is similar to Darl points, suggesting that the site may have been occupied in the Late Archaic period, but the lack of radiocarbon dates makes it impossible to confirm this.

\section{ASSESSMENT AND RECOMMENDATIONS}

Investigation of 41LT307 yielded limited cultural materials and no features. Furthermore, no associated organic material or charcoal was encountered. Though 41LT307 appears to have a Late Archaic component shallowly buried in late Holocene alluvium, the artifacts are so sparse that they are difficult to interpret. The paucity of temporally diagnostic artifacts and the lack of organic remains suggest that establishing the chronology of the occupations would be difficult. Lacking any plant or animal remains, no subsistence interpretations can be offered. The vertical distribution of materials suggests the site may not have been occupied over a long period of time, but there is no way of knowing how many occupations are represented or the total span of time. 
The part of the site that is within the current project area is recommended as being ineligible for listing in the National Register of Historic Places or designation as a State Archeological Landmark because it does not contain important information. This assessment is based on the following: (1) this part of the site contains no charcoal or other datable materials that would allow the age of the site to be confirmed; (2) this part of the site is very small and has very low densities of a limited range of kinds of artifacts and other cultural materials, suggesting that interpretable samples are not recoverable; and (3) between the trenches dug during the two phases of work and the small size of the proposed new right of way, very little of the site remains within the current project area. If significant parts of the site remain, they lie east of the proposed new right of way on private land that will not be impacted by the proposed bridge replacement. No further work is recommended.

All artifacts were generated through a statesponsored project and collected on state-owned property. All artifacts and records generated by this project are curated at the Texas Archeological Research Laboratory, The University of Texas at Austin. 


\section{REFERENCES CITED}

Blair, W. Frank

1950 The Biotic Provinces of Texas. Texas Journal of Science 2(1):93-117.

Brown, David O. (compiler)

1987 Archeology at Aquilla Lake, 1978-1982 Investigations. Research Report 81. Texas Archeological Survey, The University of Texas at Austin.

Bruseth, James E., and William A. Martin (editors) 1987 The Bird Point Island and Adams Ranch Sites: Methodological and Theoretical Contributions to North Central Texas Archaeology. Richland Creek Technical Series, Vol. II. Archaeology Research Program, Institute for the Study of Earth and Man, Southern Methodist University, Dallas.

Bureau of Economic Geology

1970 The Geologic Atlas of Texas, Waco Sheet. Bureau of Economic Geology, The University of Texas at Austin.

Davis, Michael W., Dan K. Utley, Steve A. Tomka, and Solveig A. Turpin

1987 Continuing Cultural Resource Investigations in the Calvert Prospect: The 1986 Season. Research Report No. 95. Texas Archeological Survey, The University of Texas at Austin.

Day, D. William

1984 Archeological Mitigation at the Doyle Martin Site, 41LN178, and the P. I. Ridge Site, 41FT52, Leon and Freestone Counties, Texas. Document No. 82209. Espey, Huston and Associates, Inc., Austin.

Diamond, David D., David H. Riskind, and Steve L. Orzell

1987 A Framework for Plant Communities Classification and Conservation in Texas. Texas Journal of Science 39(3):203-221.

Duffield, Lathel F.

1963 The Strawn Creek Site: A Mixed Archaic and Neo-American Site at Navarro Mills Reservoir, Navarro County, Texas. Report submitted to the National Park Service by the Texas Archeological Salvage Project, The University of Texas at Austin.
Fields, Ross C.

1995 The Archeology of the Post Oak Savannah of East Central Texas. Bulletin of the Texas Archeological Society 66:301-330.

Fields, Ross C. (editor)

1987 Excavations at the Alley Road Site (41LN30), Jewett Mine Project, Leon County, Texas. Reports of Investigations No. 61. Prewitt and Associates, Inc., Austin.

1990 Excavations at the Charles Cox, Lambs Creek Knoll, and Buffalo Branch Sites, Jewett Mine Project, Leon and Freestone Counties, Texas. Reports of Investigations No. 70. Prewitt and Associates, Inc., Austin.

Fields, Ross C., and L. Wayne Klement

1995 Excavations at the Cottonwood Springs Site, Jewett Mine project, Leon County, Texas. Reports of Investigations No. 102. Prewitt and Associates, Inc., Austin.

Fields, Ross C., L. Wayne Klement, C. Britt Bousman, Steve A. Tomka, Eloise F. Gadus, and Margaret A. Howard

1991 Excavations at the Bottoms, Rena Branch, and Moccasin Springs Sites, Jewett Mine Project, Freestone and Leon Counties, Texas. Reports of Investigations No. 82. Prewitt and Associates, Inc., Austin.

Gadus, Eloise F., Ross C. Fields, and Karl W. Kibler 2006 Data Recovery Excavations at the J. B. White Site (41MM341), Milam County, Texas. Reports of Investigations No. 145. Prewitt and Associates, Inc., Austin. Archeological Studies Program Report No. 87. Environmental Affairs Division, Texas Department of Transportation, Austin.

Gadus, E. Frances, Jennifer K. McWilliams, and Ross C. Fields

2002 Data Recovery Excavations at the McGuire's Garden Site (41FT425), Jewett Mine, Freestone County, Texas. Reports of Investigations No. 134. Prewitt and Associates, Inc., Austin. 
Griffin, Edward

1998 Soil Survey of Limestone County, Texas. United States Department of Agriculture, Soil Conservation Service, in cooperation with the Texas Agricultural Experiment Station.

Griffith, Timothy B.

2005 Archeological Survey on CR 153 at the Navasota River in Limestone County, Texas. Letter Report No. 719. Prewitt and Associates, Inc., Austin.

Mahoney, Richard B., Steve A. Tomka, Raymond P. Mauldin, Harry J. Shafer, Lee C. Nordt, Russell D. Greaves, and Rebecca R. Galdeano

2003 Data Recovery Excavations at 41MM340: A Late Archaic Site along Little River in Milam County, Texas. Archaeological Survey Report No. 340. Center for Archaeological Research, The University of Texas at San Antonio. Archeological Studies Program Report No. 54. Environmental Affairs Division, Texas Department of Transportation, Austin.

Mallouf, Michael G.

1979 Archeological Investigations at Lake Limestone. Research Report 71. Texas Archeological Survey, The University of Texas at Austin.

Mallouf, Robert J.

1981 A Case Study of Plow Damage to Chert Artifacts: The Brookeen Creek Cache, Hill County, Texas. Office of the State Archeologist Report 33. Texas Historical Commission, Austin.
McGregor, Daniel E., and James E. Bruseth (editors) 1987 Hunter-Gatherer Adaptations Along the Prairie Margin: Site Excavations and Synthesis of Prehistoric Archaeology. Richland Creek Technical Series, Vol. III. Archaeology Research Program, Institute for the Study of Earth and Man, Southern Methodist University, Dallas.

Robinson, David G., and Solveig A. Turpin

1993 Hunter-Gatherer Mobility and Settlement in the Brazos Uplands: Archeology in the Calvert Mine, Robertson County, EastCentral Texas. Studies in Archeology 14. Texas Archeological Research Laboratory, The University of Texas at Austin.

Sorrow, William M.

1966 The Pecan Springs Site, Bardwell Reservoir, Texas. Papers of the Texas Archeological Salvage Project No. 10. The University of Texas at Austin.

Yedlowski, Joseph L., Kevin J. Shaunessy, David H. Jurney, and J. M. Adovasio

1998 Archaeological Investigations in Support of the Superconducting Super Collider, Ellis County, Texas. Archaeology Research Program, Mercyhurst College, Erie.

Young, Bill, and Michael B. Collins

1989 A Cache of Blades with Clovis Affinities from Northeastern Texas. Current Research in the Pleistocene 6:26-28. 